\title{
Prototype Alat Pemantauan Ketinggian Air Pada Bendungan Menggunakan Sensor Ultrasonik Berbasis Arduino
}

\author{
Dedi Setiawan*,Ishak**,Iskandar Zulkarnaen** \\ *,** Program Studi Sistem Komputer, STMIK Triguna Dharma
}

\begin{tabular}{l}
\hline \hline Article Info \\
\hline Article history: \\
Received July 03 $03^{\text {rd }}, 2018$ \\
Revised Aug $01^{\text {st }}, 2018$ \\
Accepted Aug $05^{\text {th }}, 2018$
\end{tabular}

\section{Keyword:}

Arduino

Ultrasonic Sensor

Buzzer

$L E D$

$L C D$

\begin{abstract}
Kemajuan ilmu pengetahuan dan teknologi berperan mewujudkan kehidupan yang lebih baik. Teknologi elektronika merupakan salah satu teknologi yang telah melekat di dalam kehidupan manusia, berbagai alat elektronika praktis dan fleksibel telah banyak diciptakan sehingga membantu memudahkan manusia dalam memenuhi kebutuhannya. Baerbagai macam peralatan dengan sistem pengoperasian secara manual semakin ditinggalkan beralih pada peralatan yang serba otomatis sehingga peralatan otomatis lebih mendominasi dalam kehidupan manusia.

Rancang bangun pemantau ketinggian air pada bendungan menggunakan sensor ultrasonik berbasis arduino uno didesain dengan operasional yang sederhana sehingga mudah pengeporasian alat ini akan bekerja secara otomatis memantau ketinggian air pada bendungan. Alat ini berfungsi untuk memberi peringatan akan terjadinya banjir, jika ketinggian air pada level siaga dibendungan maka buzzer akan bunyi dengan lambat dan apabila ketinggian air pada level berbahaya maka buzzer akan bunyi dengan cepat. Dengan menggunakan alat ini, dapat membantu untuk mengetahui kapan akan terjadinya banjir, sehingga dapat memanimalisir korban akibat terjadinya banjir. Sehingga dapat mempersiapkan diri untuk mengantisipasi akan terjadinya banjir.
\end{abstract}

Copyright @ 2018 STMIK Triguna Dharma. All rights reserved.

First Author

Nama : Dedi Setiawan

Program Studi : Sistem Komputer STMIK Triguna Dharma

\section{PENDAHULUAN}

Dalam perkembangan teknologi, banyak sarana yang dirancang secara otomatis dalam membantu kegiatan manusia dalam mengatur keamanan lingkungan, begitu juga dalam pemantauan debit air pada bendungan. Bendungan dapat menampung air dalam jumlah banyak yang sangat diperlukan untuk rumah tangga, industri, pertanian, dan lain sebagainya. Dengan adanya bendungan cadangan air dapat tetap tersedia saat kemarau terjadi. Hampir pada setiap kota - kota besar di Indonesia bisa terjadi banjir pada saat musim hujan. Sehingga banyak masyarakat yang tidak tahu kapan akan terjadinya banjir dan tak jarang banjir juga dapat menimbulkan adanya korban dan banyak kerugian lainnya yang dirasakan warga. Karena tidak adanya pemberitahuan terlebih dulu untuk menghadapi kebanjiran yang akan terjadi. Maka dari itu dengan adanya pemantaun debit air pada bendungan dapat membantu masyakat untuk mempersiapkan kemungkinan akan terjadinya banjir. Bendungan dapat membantu mengatur debit air yang dialirkan melalui sungai atau saluran air. Hal ini dapat mencegah debit air berlebihan yang melewati sungai atau saluran air saat musim hujan tiba, sehingga dapat mencegah terjadinya banjir

\section{LANDASAN TEORITIS}

\subsection{Bendungan}

Bendungan atau dam adalah konstruksi yang dibangun untuk menahan laju air menjadi waduk, danau, atau tempat rekreasi. Seringkali bendungan juga digunakan untuk mengalirkan air ke sebuah Pembangkit Listrik Tenaga Air. Kebanyakan dam juga memiliki bagian yang disebut pintu air untuk membuang air yang tidak diinginkan secara bertahap atau berkelanjutan. 
Bendung adalah pembatas yang dibangun melintasi sungai yang dibangun untuk mengubah karakteristik aliran sungai. Dalam banyak kasus, bendung merupakan sebuah kontruksi yang jauh lebih kecil dari bendungan yang menyebabkan air menggenang membentuk kolam tetapi mampu melewati bagian atas bendung. Bendung mengizinkan air meluap melewati bagian atasnya sehingga aliran air tetap ada dan dalam debit yang sama bahkan sebelum sungai dibendung. Bendung bermanfaat untuk mencegah banjir, mengukur debit sungai, dan memperlambat aliran sungai sehingga menjadikan sungai lebih mudah dilalui.

Bendungan dapat membantu mengatur debit air yang dialirkan melalui sungai atau saluran air. Hal ini dapat mencegah debit air berlebihan yang melewati sungai atau saluran air saat musim hujan tiba, sehingga dapat mencegah terjadinya banjir

\subsection{Arduino}

Arduino menurut situs resminya di www.arduino.cc didefinisikan sebagai sebuah platform elektronik terbuka (open source), berbasis pada hardware dan software yang fleksibel dan mudah digunakan, yang ditujukan untuk para seniman, desainer, hobbies, dan setiap orang yang tertarik dalam membuat obyek atau lingkungan yang interaktif.

Nama Arduino tidak hanya dipakai untuk menamai board rangkaiannya saja, tetapi juga untuk menamai bahasa dan software pemrogramannya, serta lingkungan pemrograman atau IDE-nya, Integrated Development Environment.

Penulis menggunakan versi Arduino Uno cloning, sehingga yang akan dibahas tentu saja Arduino Uno. Karena versi Arduino Uno merupakan penyempurna Arduino Duemilanove, maka banyak kesamaan diantara keduanya. Perbedaan yang paling signifikan terdapat pada IC konverter USB ke serialnya. Apabila Arduino Duemilanove menggunakan IC FTDI, maka Arduino Uno menggunakan IC ATMega 16U (Arduino Uno R3) atau ATMega 8U (Arduino Uno R2) sebagai konverter USB ke serialnya.

\subsection{Sensor Ultrasonik}

Sensor Ultrasonik adalah alat elektronika yang kemampuannya bisa mengubah dari energy listrik menjadi energy mekanik dalam bentuk gelombang suara ultrasonic. Sensor ini terdiri dari rangkaian pemancar Ultrasonic yang dinamakan transmitter dan penerima ultrasonic yang disebut receiver. Alat ini digunakan untuk mengukur gelombang ultrasonic. Gelombang ultrasonic adalah gelombang mekanik yang memiliki cirri-ciri longitudinal dan biasanya memiliki frekuensi di atas $20 \mathrm{Khz}$. Gelombong Utrasonic dapat merambat melalui zat padat, cair maupun gas.

\subsection{Buzzer}

Buzzer adalah sebuah komponen elektronika yang berfungsi untuk mengubah getaran listrik menjadi getaran suara. Pada dasarnya prinsip kerja buzzer hampir sama dengan loud speaker, jadi buzzer juga terdiri dari kumparan yang terpasang pada diafragma dan kemudian kumparan tersebut dialiri arus sehingga menjadi elektromagnet, kumparan tadi akan tertarik ke dalam atau keluar, tergantung dari arah arus dan polaritas magnetnya, karena kumparan dipasang pada diafragma maka setiap gerakan kumparan akan menggerakkan diafragma secara bolak-balik sehingga membuat udara bergetar yang akan menghasilkan suara. Buzzer biasa digunakan sebagai indikator bahwa proses telah selesai atau terjadi suatu kesalahan pada sebuah alat (alarm)

\subsection{LED}

Light Emitting Diode atau sering disingkat dengan LED adalah komponen elektronika yang dapat memancarkan cahaya monokromatik ketika diberikan tegangan maju. LED merupakan keluarga Dioda yang terbuat dari bahan semikonduktor. Warna-warna Cahaya yang dipancarkan oleh LED tergantung pada jenis bahan semikonduktor yang dipergunakannya. LED juga dapat memancarkan sinar inframerah yang tidak tampak oleh mata seperti yang sering kita jumpai pada Remote Control TV ataupun Remote Control perangkat elektronik lainnya.

\section{ANALISA DAN HASIL}

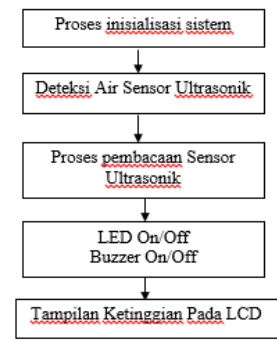

Gambar 1. Algoritma Sistem

Pada gambar merupakan algoritma terhadap permasalahan yang dimulai dari proses inisialisasi yaitu proses pendeteksian perintah awal sebelum melakukan pendeteksian input pada sensor Ultrasonik. Setelah melakukan proses inisialisasi maka dilakukan pendeteksian pada air kemudian dilanjutkan dengan proses 
verifikasi kode inputan atau pembacaan dari sensor Ultrasonik apakah perintah merespon atau tidak. Selanjutnya buzzer dan LED akan bekerja sesuai fungsinya. Dan LCD akan menampilkan ketinggian air.

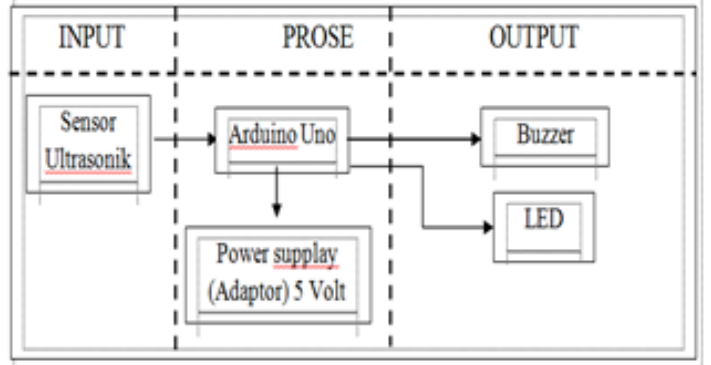

Gambar 2. Blok Diagram

Berdasarkan gambar diatas, dapat dijelaskan fungsi dari setiap masing-masing blok diagram sebagai berikut:

1. Power supplay (adaptor)

Power supplay (Adaptor) berfungsi untuk mengubah besar tegangan dari 220 Volt menjadi 5 Volt langsung ke Arduino

2. Sensor Ultrasonik

Sensor Ultrasonik berfungsi untuk mendeteksi Ketinggian Air, apabila air ada pada ketinggian tertentu akan terdeteksi maka sensor akan bekerja.

3. Arduino Uno

Arduino berfungsi untuk menerima input dari Sensor Ultrasonik digunakan sebagai pusat pengendali utama pada rangkaian

4. LED

LED berfungsi untuk mengetahui ketika berada pada level tertentu, terdapat 3 warna pada LED ini yaitu LED hijau pada saat level ketinggian air siaga, LED kuning pada saat level ketinggian air awas dan LED merah ketika level ketinggian air berbahaya.

5. Buzzer

Buzzer berfungsi sebagai menunjukkan hasil kerja dari perangkat sistem yang menghasilkan berupa bunyi.

Analisa dan Perancangan

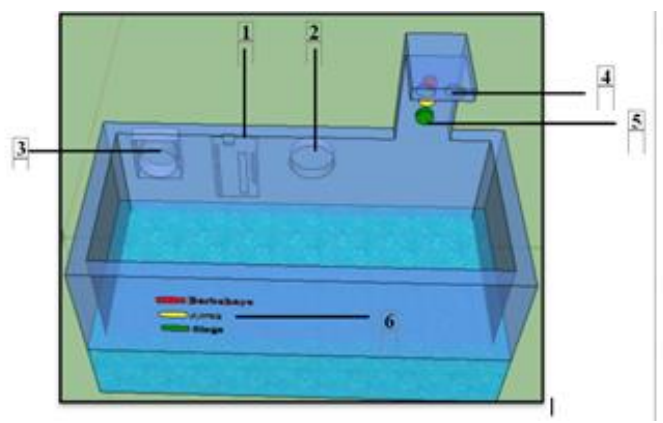

Gambar 3. Perancangan Alat

Pada gambar diatas merupakan rancangan alat pemantau ketinggian air. Pada posisi ini terlihat beberapa komponen utama pada alat

1. Arduino Uno

2. Buzzer

3. Stop kontak

4. Sensor Ultrasonik

5. LED

6. Level Ketinggian air

Sensor Ultrasonik akan mendeteksi air, kemudian sensor akan mengirim sinyal masukan ke Arduino, dan memberikan tanda pada buzzer serta LED memberikan peringatan bahwa objek terdeteksi berupa alarm. 


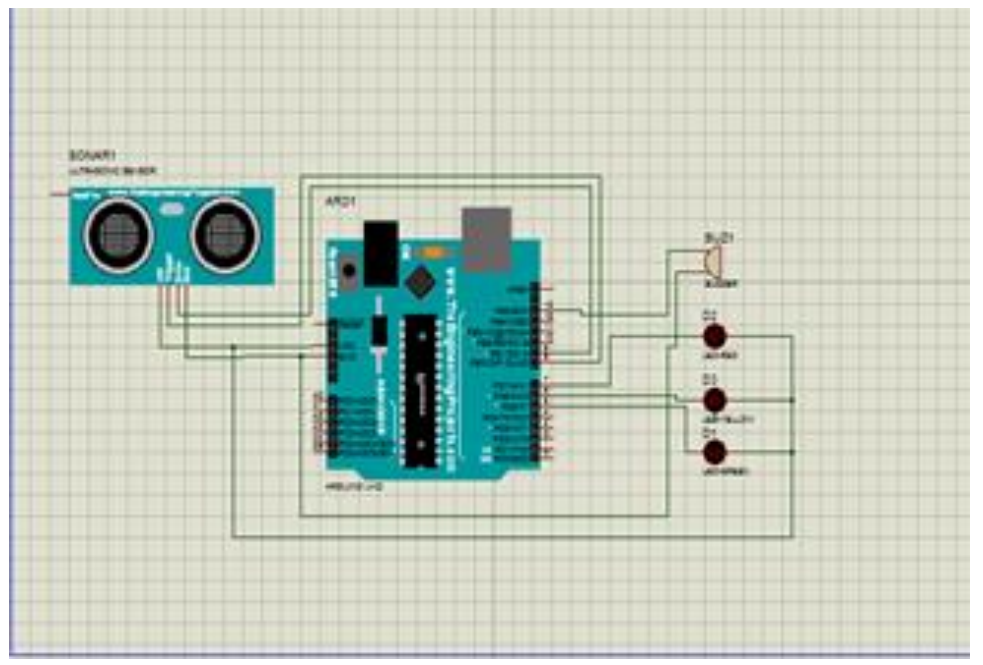

Gambar 4. Rangkaian Sistem

Rangkaian keseluruhan berdasarkan Input dan Output Komponen merupakan gabungan dari keseluruhan komponen-komponen yang digunakan. Pada rangkaian dibawah ini terlihat rancangan keseluruhan yaitu, rangkaian Arduino Uno, sensor Ultrasonik, Buzzer, dan Led. Rangkaian diatas adalah led yang dihubungkan pada pin arduino led dihubungkan ke pin 5, 6, 7 dan dihubungkan juga pada Vcc (-) dimana pin 5,6,7 merupakan data akan di proses oleh arduino uno sehingga lampu akan menyala sebagai output. Dan buzzer juga dihubungkan pin arduino dan Gnd (+). Pin pada sensor ultrasonik ada 4 pin yaitu Pin Vcc(-) dihunbungkan pada rangkaian arduino 5 Volt, pin Tring dan echo dihubungkan pada pin 7 dan 8 yang ada pada arduino pada pin inimerupakan data yang aka diproses oleh arduino sehingga sensor ultrasonik dapat bekerja sebagai input. Dan pin Gnd (+) pada sensor ultrasonik di hubungkan pada Gnd yang ada pada arduino.

Tabel 1. Pengukuran Alat

\begin{tabular}{|c|c|c|c|}
\hline No. & Nama Komponen & Keadaan & Volt Komponen \\
\hline \multirow{2}{*}{1} & \multirow{2}{*}{ Sensor Ultrasonik } & Terdeteksi & 5 Volt \\
\hline & & Tidak Terdeteksi & 0.1 Volt \\
\hline \multirow{2}{*}{2} & \multirow{2}{*}{ Buzzer } & On & 5 Volt \\
\hline & & Off & 0.1 Volt \\
\hline \multirow{2}{*}{3} & \multirow{2}{*}{ LED } & Nyala & $2.5 \mathrm{Volt}$ \\
\hline & & Padam & 0.1 Volt \\
\hline \multirow{2}{*}{4} & \multirow{2}{*}{ LCD } & Nyala & 4.0 Volt \\
\hline & & Padam & 0.1 Volt \\
\hline
\end{tabular}

\section{KESIMPULAN}

4.1 Kesimpulan

Dari hasil penelitian dan pembahasan yang telah dilakukan untuk menjawab setiap topik permasalahan, maka dapat disimpulkan beberapa hal sebagai berikut :

1. Dengan memanfaatkan sensor Ultrasonik sebagai sensor yang akan mendeteksi objek-objek dengan prinsip kerja yaitu merespon energi dari gelombang pantulan yang dimilik oleh setiap benda yang terdeteksi.

2. Implementasi sensor Ultrasonik sebagai sensor pendeteksi objek (air) di bendungan serta mikrokontroler Arduino sebagai pengendali yang mengendalikan aktuatis buzzer yang digunakan sebagai alarm.

3. Manfaat buzzer sebagai alarm yang berfungsi untuk memberi informasi ketinggian air tertentu, sehingga dapat megurangi resiko terjadinya korban akibat banjir.

4. Manfaat LCD untuk menampilkan hasil lair pada ketinggian tertentu

5. Manfaat LED adalah untuk mengetahui ketinggian air pada level tertentu.

\subsection{Saran}


1 Semua benda yang terdeteksi oleh sensor ultrasonik dianggap air.

2 Cara kerja alat ini masih lambat untuk membaca objek yang akan di deteksi.

3 Mahalnya biaya dalam perancangan alat pemantauan ketinggian air pada bendungan.

4 Tidak adanya sumber daya cadangan untuk memaksimalkan kerja alat ketika aliran listrik padam.

$5 \quad$ Sistem yang dirancang harus dilakukan pemeriksaan secara berkala.

\section{REFERENSI}

[1] http://dasarelektronika.com/pengertian dan fungsi/

[2] http://www.produksieletronika.com/2013/10/cara-prinsip-kerja-sensor/

[3] http://digilib.mercubuana.ac.id/

[4] Kadir. Abdul, 2013, PENGENALAN ALGORITMA, Yogyakarta; CV;Andi Offset.

[5] Team work STMIK TRIGUNA DHARMA,2014 Workshop TA/Skripsi,Medan

\section{BIBLIOGRAFI PENULIS}

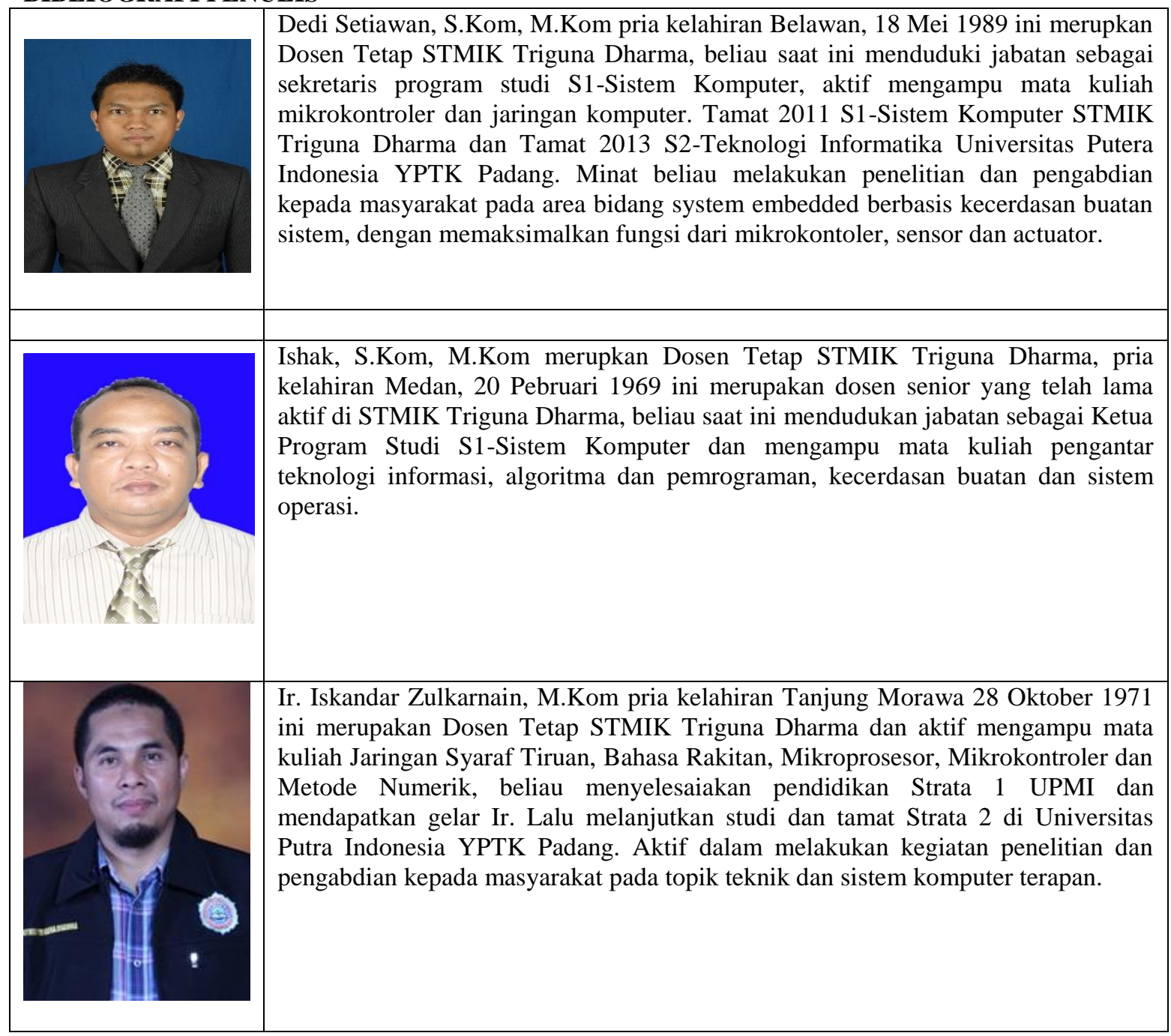

